\author{
Никола В. РАДОСАВЉЕВИЋ \\ Филолошки факултет \\ Универзитета у Београду
}

\title{
АКЦЕНАТ У ПРЕФИКСАЛНОЈ ТВОРБИ ИМЕНИЦА
}

\begin{abstract}
У раду се са синхронијског становишта испитују прозодијске алтернације између именица насталих префиксацијом и њихових мотивних речи. Даје се типологија акценатских алтернација према прозодијским критеријумима (место и квалитет акцента, квантитет слогова) и присутним творбеним моделима. Разматра се природа приказаних алтернација и указује се на могућа друга акценатска решења. Циљ рада је да се покуша допринети проучавању акцента у творби речи.
\end{abstract}

Кључне речи: савремени српски језик, прозодија, акценат речи, акценатске алтернације, префиксација, именице.

\section{0. Увод}

0.1. Предмет рада је акценат именица савременог српског језика насталих префиксалном творбом речи и њихових мотивних речи.

Под префиксалном творбом речи или префиксацијом (у даљем тексту: ПТ) подразумевамо творбени начин у којем се пуној мотивној речи с леве стране додаје афикс, са модификационим значењем, при чему врста речи остаје иста (Ћорић 2008б, 2015; Драгићевић 2008: 64-65; 2015: 357); разматрање места ПТ међу другим творбеним начинима не улази у предмет овог рада. ${ }^{1}$

0.2. Акценат у творби речи је слабо истражена област савременог српског језика. То нарочито важи за префиксацију. У чланку Ј. Јокановић Михајлов налази се занимљиво запажање о акценатским карактеристикама негације (2012: 88-94) и скреће се пажња на различит акценатски однос именица миิр : нёмйр и срёћа : нѐсрећа. Колико нам је познато, системски се акцентом у префиксацији именица на материјалу српског језика бавио једино М. Дешић (2018). У корпусу за наведени рад пак нису одвојени примери са префикси-

\footnotetext{
${ }^{1}$ Више о томе в. у: Клајн 2002; Радић 2005; Ћорић 2008б, 2015; Драгићевић 2015.
} 
ма од примера са префиксоидима. Аутор је грађу поделио примарно према „лексичким акцентима”, који се односе на основну реч и „префиксал” (термин је очито према Клајн 2002), а унутар те класификације сваку од група на подгрупе према „морфолошким акцентима”, тј. акцентима облика основне речи и префиксала:

1) лексички акценат је на основи префиксала и:

a) нема промене акцента ни у основној речи ни на префиксалу: нпр. симѐтрија : асимѐтрија;

б) акценат се може променити само у парадигми основне речи: нпр. фа̀mиста, ген. мн. фӓшӣста̄ : антифа̀шиста;

в) промена акцента се јавља и у основној лексеми и у префиксалу, при чему акценат не прелази на префикс - нпр. ло́по̄в, ло́nова : архило́по̄в, архило́пова - или прелази на префикс - нпр. пу̀ша̄ч, пуша́ча, вок. пӱша̄чу : непу̀ша̄ч, непуша́ча, вок. нёпуша̄чу;

2) лексички акценат је на префиксу - код примера са акцентом на префиксу, за оне где је основна лексема са силазним акцентом, он употребљава термин проклитичко преношење, а за оне где је основна лексема са узлазним, преклитичко преношење:

a) где нема промене акцента ни у основној лексеми, ни у префиксалу: нпр. рёктор : про̀ректор, си́нус : коेсинус;

б) с променом акцента само у парадигми основне речи: нпр. ре̂д, лок. јд. ре́дy, ном. мн. рёдови : нёре̄д; ста̀на̄p, ген. јд. стана́ра, вок. јд. стӓна̄py : пӧдстана̄p;

в) с променом акцента и у основној лексеми и у префиксалу, где морфолошки акценат у префиксалу може бити на префиксу

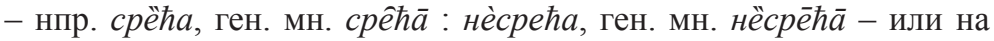
основи - нпр. спрӓт, ген. јд. спра̀ma/cnpäma : мёђуспрат, ген. јд. међуспра̀ma/мёђуспрата - или и на једном и на другом делу, зависно од граматичког броја - нпр. вре́ме, ген. јд. врёмена, ном. мн. времѐна, ген. мн. време́на̄ : нёврёме, ген. јд. нёвремена, ном. мн. невремѐна, ген. мн. невреме́на̄.

Аутор наводи и дублете међу поменутим групама (наводимо по пример за сваку различиту врсту акценатског односа):

1) лексички акценат је дублетан:

a) једноакценатски или двоакценатски префиксал: револу́ичија - контрареволу́ијја/кӧнтрареволу́ичија, на̀ука/на́ука - псеудона̀ука/псёудона̀ука и псеудона́ука/псёудона́ука;

б) дублетној основној речи одговара дублетни префиксал, једноакценатски или двоакценатски: ха̀рмо̄нија/хармо̀нија - дисха̀рмо̄нија/дисхармо̀нија, заิрада/зӓрада - нйззаิрада/ нӥззӓрада; 
в) код једног члана дублетног префиксала акценат је исти као на основној речи, а други има силазни на префиксу, узлазни на префиксу или се мења акценат основне речи са силазног на узлазни: ӱслуга - противйслуга/прӧтивуслуга, сйла - суперсйла/ су̀nерсила, на̂nаd/на́nад - противна̂nаd/противна́nад;

г) акценат је на префиксу, силазни или узлазни: смиิсао - бёсмӣсaо/ бѐсмйсао;

д) квантитет је дублетан: коิнзул/кӧнзул - вӥцеко̄нзул/ вйцеконзул;

2) морфолошки акценат је дублетан, где један члан чува акценат основне речи, а други га проклитички преноси: ген. јд. врёмена - ген. јд. међу̀времена/међуврёмена, ном. мн. стӓвови/ ста̀вови - ном. мн. прӧтивставови/ противста̀вови;

3) два примера која због сложености посебно издвајамо: пре-

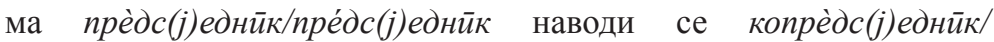

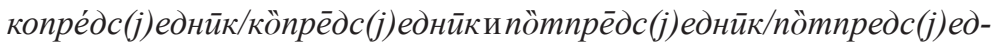

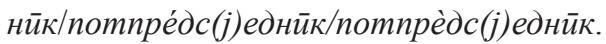

У раду се закључује да се у наведеним групама могу наћи именице с различитим префиксима.

Врло је значајно ауторово запажање да префиксалне именице често имају исти акценат као непрефиксалне, а посебно његово указивање на бројне примере за које сматра да се изговарају с два акцента, као и став да силазне акценте на унутрашњим слоговима именица насталих префиксалном творбом у одређеним случајевима (уп. т. 1.3.3) треба прихватити као стандардне, са чим се начелно слажемо:

„Кад се силазни акценти нађу на ОП [основи префиксала, нап. Н. Р.], преузети из О [основне речи, нап. Н. Р.], доспију на унутрашње слогове ријечи, што се коси са основним правилима српске акценатске норме. Међутим, овакве акценте требало би прихватити као стандардне, јер су већ били на почетку основне ријечи, а и сада су у почетном дијелу, одмах иза префикса. У ствари, овдје се, као и у претходним примјерима, огледа тежња да се сачува акценат O.” (Id.: 181)

0.3. Акиеенатске алтернације (Николић 1962) у творби речи, као односе прозодијских карактеристика мотивисаних и њихових мотивних речи, анализирамо са становишта акценатске норме савременог српског стандардног језика, која је заснована на принципима Вук-Даничићеве акцентуације (изложеним у: Даничић 1925; Белић 1914; Пецо - Пешикан 1967; Стевановић 1991; Јокановић-Михајлов 2006: 121-200).

Корпус именица насталих ПТ је ексцерпиран из до сада завршених речника савременог српског стандардног језика - Речника српскохрватскога къижевног језика Матице српске (1967-1976), у даљем тексту РМС6, и Речника српскога језика Матице српске (2011), у даљем тексту РСЈ2011 - као и из Обратног речника српскога језика Мирослава Николића (2005), у даљем тексту ОР. Након извршене творбене анализе (по принципима из Ћорић 2008б, потпомогнути радовима Клајн 2002; Радовић Тешић 2002), из истих речника ексцерпиране су и одговарајуће мотивне речи за сваку мотивисану. 
У корпус не убрајамо:

1) лексеме са страном препозитивном компонентом у првом делу (Ћорић 2008б), најпре због неједнаког статуса тих форманата у дериватологији (Драгићевић 2015: 362), али и због неуједначености у правописној пракси, које у бројним случајевима доводе у питање је ли реч о једној речи или две (Брборић 2012);

2) лексеме у чијој творби утичу веле-, полу- и слични форманти који су на граници између префикса, префиксоида и основа;

3) именице на -(н)ик типа несрећник, које се једноставно могу извести из придева (њихов акценат је увек једнак акценту мотивног придева, уз сталну дужину на слогу суфикса);

4) именице на -(н)ица типа непотписницуа, неузданицุа, санаследница, сунаследница..., које сматрамо резултатима суфиксације од одговарајућих именица на -(н)ик (акценат именица на -(н)щца иначе је истоветан акценту именица на -(н)ик, са изузетком одбијања тог суфикса и постакценатске дужине на њему, разуме се); неке од њих имамо у грађи;

5) именице на -(н)ост типа надуљудност, које сматрамо резултатима суфиксалне творбе од одговарајућих придева на - $(a) H /$-ни (акценат ових именица иначе је истоветан акценту придева од којих су творене и/или је дугоузлазни пред суфиксом -оcm, уз постакценатску дужину на том суфиксу у ном. јд. и акуз. јд.).

Ијекавски облици се не наводе, будући да су раније утврђена и описана правила њиховог акценатског разликовања од екавских (Јокановић Михајлов 2013: 32-37).

0.4. Задаци су следећи:

1) да се корпус класификује према:

а) акценатским елементима који алтернирају између мотивних и мотивисаних речи - месту акцентованог слога, тону и квантитету слогова;

б) творбеним типовима - у какве све акценатске односе с мотивном речју улазе именице додавањем појединих префикса;

в) лексикографској обради акценатских алтернација између именица насталих ПТ и њихових мотивних речи у поменутим речницима - има ли лексема које нису заступљене у свим коришћеним речницима и постоје ли разлике у обради појединачних лексема у различитим речницима;

2) да се пробају анализирати и протумачити фактори који доводе до примећених акценатских алтернација, пре свега фонолошки процеси и процеси у домену интерфејса фонологије и творбе речи, али евентуално и омашке или недоследности лексикографа̂ у акцентолошкој обради. 
0.5. Циљеви рада су следећи:

1) изложити типологију акценатских алтернација између именица насталих ПТ и њиховних мотивних речи према прозодијским и творбеним критеријумима;

2) утврђивање фактора који доводе до акценатских алтернација у ПТ, с посебним нагласком на присуство акцента који није условљен искључиво фонолошким процесима - творбено мотивисаног акцента;

3) регистровање недостатака у лексикографској обради анализираног корпуса, са жељом да се помогне њиховом исправљању;

4) предлагање конкретних акценатских ликова којима се могу допунити постојећа решења;

5) у целини, да се покуша допринети проучавању и разумевању акцента у творби речи савременог српског језика.

1. Типологија акценатских алтернација у префиксалној творби именица: место и квалитет акцента

\section{1. Мотивна именица има силазни акиченат}

1.1.1. ТИП П0 - мотивисана именица је с краткосилазним на првом слогу (префиксу)

1.1.1.1. Преглед по префиксима:

\begin{tabular}{|c|c|}
\hline без- & бёсвёст : свеิст, бёстра̄г : траิг \\
\hline ван-* & вӓнпривреда: прйвреда \\
\hline до-* & 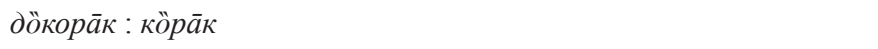 \\
\hline 3a- & зӓокука: ӧкука \\
\hline мeђу- & мёђуакт : а̀кт, мёђучйн : чиิн \\
\hline мимо- & мӥмохо̄д : хоิд \\
\hline над- & нӓдвојвода : вӧјвода, нӓдмо̄ћ : моิћ \\
\hline не- & 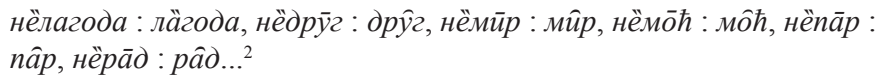 \\
\hline по- & пӧгово̄ $p^{3}:$ гӧво̄p \\
\hline под- & 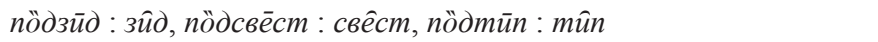 \\
\hline
\end{tabular}

\footnotetext{
${ }^{2}$ Још и: нёре̄д : ре人д, нёсве̄сm : све̂ст.

${ }^{3}$ Осим ако није нултим суфиксом од поговорити, угледањем на уговорити : уговор и сл.

${ }^{4}$ РСЈ2011 и ОР само мотивну реч обрнутим редоследом.
} 


\begin{tabular}{|c|c|}
\hline пра- & прӓмати : мӓти, праилиик : ликк, прӓдоба/прӓдо̄ба : дӧба/добба \\
\hline пре- 1. & прёслава : слӓва \\
\hline пре- 2. & прёвла̄ст : влаิст, прёмо̄ћ : моิћ \\
\hline пред- & $\begin{array}{l}\text { прёдгово̄р : гӧворр, прёдистрага : йстрага, прёдјело : јёло, } \\
\text { прёдспрема : спрёма... }\end{array}$ \\
\hline при- & прйпомо̄ $\hbar^{5}:$ пӧмо̄ћ, прймйсао : мйсао \\
\hline против- & 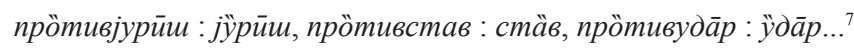 \\
\hline раз-* & рӓзба̄н: баิн \\
\hline ca- & 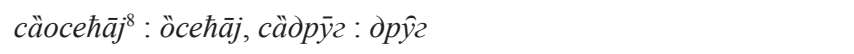 \\
\hline cy- & 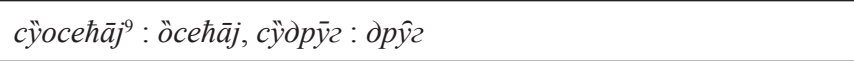 \\
\hline
\end{tabular}

За префиксе означене звездицом (*) нема потврде у свим речницима: дӧкора̄к даје само РМС6, вӓнпривреда само ОР и рӓзба̄н само РМС6.

Исто важи за следеће примере:

1) префикс без-: само у РМС6 и ОР: бёспомо̄ $\hbar^{10}$ : пӧмо̄ћ, бёзгла̄с : глаิс;

2) префикс међу: само ОР: мёђувеза : вёза, мёђупостава : пӧстава, мёђупресуда : прёсуда; само РМС6: мёђутӣn : mûn; само ОР: мёђубро̄j : броิj;

3) префикс мимо-: РМС6 и ОР: мймолетm : ле̂т;

4) префикс над-: РМС6 и ОР: нӓдмлина̄p : млйна̄p, нӓдсве̄m : све̂т;

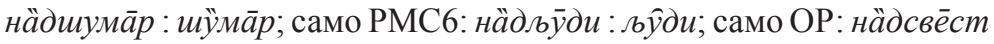
: свёст;

5) префикс не-: РМС6 и ОР: нёобзӣр : ӧбзйр, нёопрёз : ӧпрёз, нёсла̄ст : слаิст, нёсмйсао : смйсао, нёудаја: :̈даја, , нёча̄ст : чаิст; ОР и PCJ2011: нёпривреда : прйвреда; само РМС6: нёборг : борг; само ОР: нёкрев : күิв, нёпотреба : пӧтреба;

6) префикс по-: РМС6 и ОР: пӧкћй : кћй;

7) префикс под-: РМС6 и ОР: пӧтиентар : цүёнтар, пӧдба̄н : баิн,

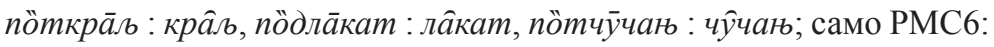
пӧдђакон : ђӓкон, пӧтчаснӣк : чӓснйк;

8) префикс пра-: РМС6 и ОР: прӓтетка : тётка, прӓбйљка : биิљка, прӓвёк : веек; РМС6 и РСЈ2011: прӓслика : слйка;

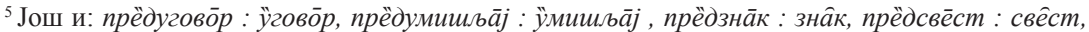

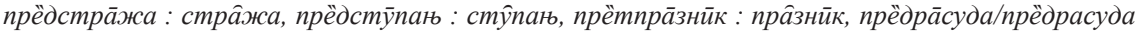
(ОР и РСЈ2011 обрнутим редоследом) : рӓсуда/ра̂суда.

${ }^{6}$ Осим ако није нултим суфиксом од припомоћи.

${ }^{7}$ Још и: прӧтивуслуга : ӱслуга, прӧтивтёло : телло.

${ }^{8}$ Осим ако није суфиксацијом од саосећати.

${ }^{9}$ Осим ако није суфиксацијом од суосећати.

${ }^{10}$ Осим ако није нултим суфиксом од беспомоћан или сл.
} 
9) префикс пре- 2: РМС6 и ОР: прёјад : jäд, прёпаме̄m : пӓмёm, прёсја̄j : cjâj;

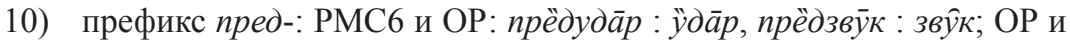
РСЈ2011: прётпродаја : прӧдаја; само ОР: прёдобјава : ӧбјава;

11) префикс при-: РМС6 и ОР: прӥмирйс : мйрӣс, прӥпаша ${ }^{11}$ : пӓша,

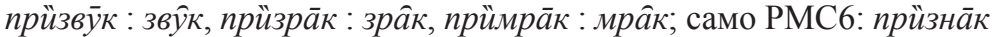
: знаิк, прӥра̄д : ра̂̀;

12) префикс против-: РМС6 и ОР: прӧтивмера : мёра, прӧтивпригово̄р : прйгово̄р, прӧтивте̄г : те̂г;

13) префикс раз-: РМС6 и ОР: рӓскнёз : кнеิз;

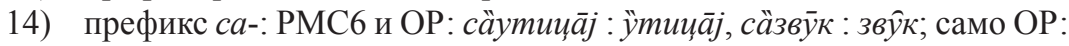

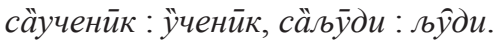

1.1.1.2. По заступљености лексема у корпусу, ово је доминантан тип кад је мотивна реч са силазним акцентом. Алтернација се може тумачити на два начина.

1) Префиксацијом се овде неутрализује акценат мотивне речи, а потом се реализује силазни акценат на првом слогу као немаркирани акценат у нашем језику. Силазни тон у светским језицима обично се сматра немаркираном реализацијом тона, тј. сматра се да се силазни тон на лексеми јавља када нема ниједног другог слога који привлачи виши тон (Фокс 2000; Јип 2006). Тако би краткосилазни на префиксу заправо био неутрални краткосилазни на првом слогу лексеме, реализован као неутрални акценат.

2) Творбени модел подразумева да први (/једини) слог префикса привлачи високи тон. Тиме би се резултат схватио као превага акцента префикса над акцентом мотивне речи. Ово решење нам је ипак даље, јер смо скептични према тврдњи да у савременом српском језику од два акцента у речи слаби онај десни; нама пре изгледа обрнуто - у речима с два акцента очекиваније је да слабији буде онај с леве стране, до те мере да можда постаје секундарни акценат ${ }^{12}$.

1.1.1.3. Има примера за које смо сигурни да се могу изговорити и са два акцента. То су пре свега лексеме с међу- и против-: мёђуӓкт, мёђучиิн, мёђувёза, мёђупӧстава, мёђупрёсуда, мёђуброิ; прӧтивјӱрӣш, прӧтивстӓв, прӧтивӱда̄p, прӧтивмёра, прӧтивпрйгово̄p, прӧтивтеิг, али и вӓнпрӥвреда и неки примери са пра- (уп. прӓмӓтеро у: Маројевић 2011), нарочито ако се узме у обзир цела парадигма. То не мора значити да су у тим случајевима акценти једнаке јачине и квантитета - акценат на (првом) слогу префикса може бити секундарни акценат. Ове случајеве тумачимо као исход прозодијске евалуације метричке структуре целе лексеме - у случају два акцента за прозодијски систем делови лексеме нису потпуно срасли у целину. Силазни се у тим случајевима (поново) реализује као неутрални, немаркирани тон.

\footnotetext{
${ }^{11}$ Осим ако није суфиксацијом од глагола припасти (према пасти : пасем).

${ }^{12}$ У србистици је уведен термин побочни акценат (Маројевић 2011, 2012).
} 


\subsection{2. ТИП П1 - мотивисана именица је с краткоузлазним акцентом} на слогу испред акцентованог слога мотивне речи

\subsubsection{1. Преглед по префиксима:}

\begin{tabular}{|c|c|c|}
\hline \multicolumn{2}{|l|}{ без- } & бѐзбрига : брйга, бѐзвоља: вӧља \\
\hline \multicolumn{2}{|c|}{ међу-* } & међу̀јело : јёло \\
\hline \multicolumn{2}{|c|}{ на- $*$} & на̀субийа : гўбийа \\
\hline \multicolumn{2}{|c|}{ над-* } & 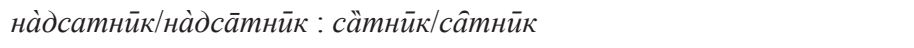 \\
\hline \multicolumn{2}{|l|}{ не- } & нѐбрат : брӓт, нѐбрига : брйга, нѐдело : дёло, нѐзет : зёт, нѐјело : јёло... ${ }^{13}$ \\
\hline \multicolumn{2}{|l|}{ по- } & по̀мати : мӓти \\
\hline \multicolumn{2}{|c|}{ под- } & $\begin{array}{l}\text { по̀дгрло : гёло, по̀дмишка : мйшка, по̀дсукњ } а: \text { сӱкњ } а, \text { по̀дтекст : } \\
\text { тёкст }\end{array}$ \\
\hline \multicolumn{2}{|c|}{ пред- } & 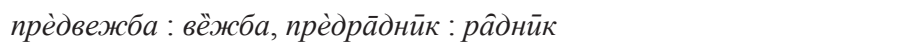 \\
\hline \multicolumn{2}{|c|}{ при-* } & прйсен : сён \\
\hline \multicolumn{2}{|c|}{ pa3- } & pàcu̧ap : u̧äp \\
\hline \multirow[t]{2}{*}{ ca- } & ca- & 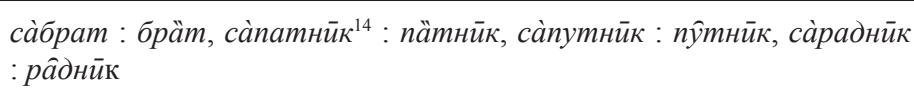 \\
\hline & cy- & су̀власнӣк : влӓснйк, су̀грађанин : грӓђанин \\
\hline
\end{tabular}

За префиксе означене звездицом (*) нема потврде у свим речницима:

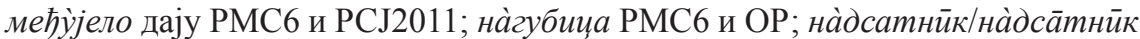
даје само ОР, а РМС6 по истом типу, али нема доследно квантитет: на̀дса̄тнйк :

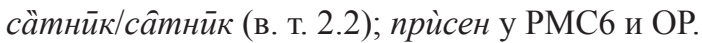

Исто важи за:

1) префикс по-: РМС6 и ОР: по̀брат : брӓт;

2) префикс под-: РМС6 и ОР: по̀шав : шӓв, по̀тпокре̄m : пӧкре̄т; само РМС6: по̀дмост : моेсm;

3) префикс пред-: ОР и РСЈ2011: прѐтчас : чӓс;

4) префикс при-: само РМС6: прѝглас : глаิс.

1.1.2.2. Ових примера је знатно мање него оних по типу П0. Алтернација је производ фонолошког процеса - преношења акцента с мотивне речи на слог испред уз промену тона, тј. метатоније (за основно о метатонији в.

${ }^{13}$ Још и: нѐсрећa : cpëћa, нѐnра̄вда : пра̂вда. Но, овде фактички спадају и све глаголске именице типа нѐверова̄ње, нѐгледа̄ње, нѐпева̄ње, нѐслуша̄ње, нѐпра̄вда̄ње итд., у чијој је структури глагол са силазним акцентом у инфинитиву, ако се схвате као резултати префиксације, негације од већ творених глаголских именица вёрова̄ње, глёда̄ње, слйша̄ње итд. Све оне могу се пак тумачити и као директно творене од глагола, чиме улазе у префиксално-суфиксални, односно суфиксални творбени начин, зависно од схватања.

${ }^{14}$ Осим ако није префиксално-суфиксалном творбом од патити. 
Белић 1914). Дакле, основна разлика у односу на претходни тип, П0, јесте што само додавање префикса није неутралисало тон мотивне речи: добило се најпре небрйга, непраิвда и др., па се тек фонолошким процесом акценат померио на слог испред. То значи да акценат на префиксу није у директној вези са самом творбеним начином, већ последица забране силазног ван првог слога речи у овим случајевима.

1.1.2.3. Између нёсећа̄ње у РМС6 и нѐсећа̄ње у ОР, други сигурно даје право решење (уп. фусноту 17).

\section{2. Мотивна реч има узлазни акценат}

\subsection{1. ТИП М0 - акценат мотивисане именице је узлазни на акцентованом слогу мотивне речи ${ }^{15}$}

\subsubsection{1. Преглед по префиксима:}

\begin{tabular}{|c|c|}
\hline ван-* & вансезо́на \\
\hline до- & допо́dне $e^{16}$ \\
\hline међу- & међувре́ме \\
\hline мимо-* & мимопро̀лазнйк \\
\hline над-* & натпа̀стӣp, надса́ветнӣк \\
\hline не- & $\begin{array}{l}\text { невештйна, неплѝва̄ч, неслобо̀да, неби́так, неби́ће, недисиипли́на, не- } \\
\text { парти́јаи.... }\end{array}$ \\
\hline по- & попо́дне \\
\hline под- & подварија̀нта, поддија̀лекат, подо̀дељак, подсекрѐта̄p, подсѐкиија... ${ }^{18}$ \\
\hline пра-* & прадавнйна \\
\hline пре- 1. & препо́дне ${ }^{19}$ \\
\hline пре- 2.* & прегрехо̀та \\
\hline
\end{tabular}

${ }^{15}$ У табелама не наводимо мотивну реч ако акценат и његово место на мотивисаној именици остају потпуно исти као код мотивне речи.

${ }^{16}$ Ако није резултат конверзије (Клајн 2002: 183-184).

${ }^{17}$ Још и: несра́змера, непа̀жња/непа́жња (ОР само обрнутим редоследом) : па́жња/па̀жња . Но, паралелно примерима у фусноти 17, негацијом већ творених глаголских именица са узлазним акцентом у инфинитиву добили бисмо бројне примере који иду у ову групу: неприेстаја̄ње, непла́ћа̄ње итд. Иако се и многе од њих могу схватити као резултат префиксално-суфиксалне или суфиксалне творбе, у овој пак акценатској групи, и то кад је дугоузлазни испред -ње, има примера код којих јасније осећамо семантику негиране именице него глаголске радње, нпр. незна́ње, неповере́ґе, непризна́ғе и др.

${ }^{18}$ Још и: потконтѝнент, подза́куп, подна́реднӣк, подна́слов, подра́зред, подса́вез, потпи́mārbe.

${ }^{19}$ Ако није резултат конверзије као доподне (в. фусноту 16). 


\begin{tabular}{|c|c|}
\hline пред- & $\begin{array}{l}\text { претпро̀јекат, претпро̀леће, предзна́ње, предра́дња, предсезо́на, } \\
\text { предубеђе́ње... }\end{array}$ \\
\hline против- & протива̀киија, противкандйда̄т, противоттров ${ }^{21}$, противу̀дараи $u^{22}$ \\
\hline ca- & сабѐседнйк, сайгра̄ч, саинвѐстйтор, сапо̀тпис, сапо̀тписнйк, саде́јство \\
\hline cy- & $\begin{array}{l}\text { субѐседнӣк, сувѐсла̄ч, сувла̀далаи, сувла̀да̄p, суоптужѐнйк, суоснйва̄ч, } \\
\text { сусвојйна...23 }\end{array}$ \\
\hline
\end{tabular}

За префиксе означене звездицом (*) нема потврде у свим речницима: вансезо́на у ОР и РСЈ2011; мимопро̀лазнйк у РМС6 и ОР; натпа̀стӣp, надса́ветнйк у РМС6 и ОР; прадавнѝна у РМС6 и ОР; прегрехо̀та само у PMC6.

Исто важи за:

1) префикс међу-: у РМС6 и ОР: међувла́да; у ОР и РСЈ2011: међуфа́за; само у РСЈ2011: међупа̀луба; само у ОР: међупро́стор/ међупроेстор, међусрѐдство, међуце́на;

2) префикс над-: само у РМС6: надуччтель, натконтро̀ло̄p,

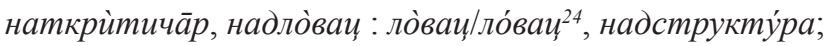

3) префикс не-: РМС6 и ОР: невероватно̀ћа, нейгра̄ч, непрежѝва̄ч, невесе́ље; ОР и РСЈ2011:несло̀вён, нечисто̀ћа,нена́сйље/нена́сиље ${ }^{25}$; само PМС6: нена́ука/нена̀ука; само ОР: неама̀те̄p, небѝра̄ч, негла̀са̄ч, недемокра̀тија, неинтелигѐнција, немудрйја̄ш, непѐва̄ч, непрера̀ђевина/непрерађѐвина ${ }^{26}$, непроизво̀дња/непроизво́дња, ${ }^{27}$ непрофесиона́лаи, неравноте́жа, неслове́нац;

4) префикс под-: РМС6 и ОР: подадмйра̄л, подбѐлежнӣк, подсу̀дија, поду̀читељ, потканцеела̄p, поткапѐта̄н, поткома̀ндйр, потпо̀гла̄вље, подна́јам, подна́челнӣк, подра́здо̄бље, подна́дзорнӣк/

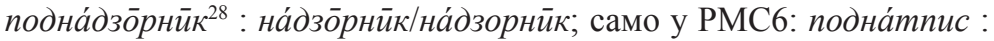
на́тпис/на̀тпис, ${ }^{29}$ подза́лог;

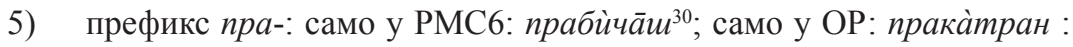
ка̀тран, прау̀зор/прау́зор;

6) префикс пред-: РМС6 и ОР: предтѐре̄н, предту̀рнӣр, преду̀дарац, претконферѐниија, преткониѐнтра̄т, предсу́тон, претконщентра́щија, преду̀nис : у̀nис/ýnис;

\footnotetext{
${ }^{20}$ Још и: предувере́ње, преткалкула́ичија, претпремије́ра.

${ }^{21}$ РМС6 даје ӧтро̄в само с квалификатором покр. и у загради.

${ }^{22}$ Још и: противагита́ција, противвре́дно̄ст, противофанзи́ва, противпре́длог, противра́злог, противреформа́ција, противте́жа.

${ }^{23}$ Још и: суфинансѝје̄p, судр’жављанин/судржа́вљьанин, супо́сед/супо̀сед (РСJ2011 даје по̀сед у загради), супо́седнйк/супо̀седнӣк.

${ }^{24}$ ОР други лик мотивне речи у загради, а РСЈ2011 само први лик.

${ }^{25}$ РСЈ2011 само префиксале обрнутим редоследом.

${ }^{26}$ РМС6 даје мотивну реч само обрнутим редоследом.

${ }^{27}$ РМС6 само мотивну реч обрнутим редоследом.

${ }^{28}$ ОР само обрнутим редоследом.

${ }^{29}$ ОР и РСЈ2011 за мотивну реч дају само на́тпис.

${ }^{30}$ За мотивну реч даје и бйча̄u, али се не зна да ли се односи на одговарајућу лексему.
} 
7) префикс против-: РМС6 и ОР: противреволу́ција; само РМС6: противсрѐдство, противде́јство, противра́дња; само ОР: противна́лог, противна́редба;

8) префикс са-: РМС6 и ОР: саугова̀ра̄ч, саодлучи́ва̄ње, сапо́седнӣк/ сапо̀седнйк; само у РМС6: сара́змера;

9) префикс су-: РМС6 и ОР: сувѐжба̄ч.

1.2.1.2. По заступљености у речницима доминантни тип када је мотивна реч с узлазним акцентом. Тип показује одсуство алтернације, што може значити једну од две ствари:

1) префиксација је потпуно неутрална у односу на тон ових мотивних речи;

2) између једне тежње - мотивне речи да задржи свој акценат - и друге тежње -префикса да неутралише акценат мотивне речи или да наметне свој краткосилазни акценат (в. т. 1.1.1.2) - превагу односи прва.

1.2.1.3. И у овом типу проналазимо лексеме за које мислимо да се могу чути с два акцента или са секундарним акцентом на првом слогу.

Најпре су то поново примери с двосложним префиксима међу- и против- (уп. т. 1.1.1.3), мада треба напоменути да нам и сви примери с једним акцентом сасвим природно звуче (што је значајна разлика у односу на примере код типа П0 и П1). Изузетак је можда једино противреволу́ција, за коју бисмо рекли да би обичнија била као прӧтивреволу́ција (или можда са секундарним акцентом на против-); рекли бисмо да је овакве примере теже изговорити с једним акцентом што је акцентовани слог мотивне речи удаљенији од њеног почетка.

Но, поред њих, изгледа да чување узлазног на унутрашњем слогу узрокује јављање ослонца на првом слогу и у још једном случају - кад је морфемска граница између префикса и мотивне речи ојачана консонантском групом унутар које пада јака слоговна граница. Узлазни мотивне речи се и даље чува према правилу, али је због теже изговорљивости потребан и други, можда секундарни, акценат на првом слогу. То би били примери као што су вӓнсезо́на (можда из истог разлога и вӓнпрӥвреда из т. 1.1.1.3), прётпројјекат, прёдсезо́на, прёдту̀рнйр и др., а нарочито кад је узлазни још даље од слога префикса, нпр. прётконферѐнциија, прётконщентра́цฺија и сл.

1.2.1.4. Сматрамо да су изостали, сасвим обични, сӓбеседнйк и сӓигра̄ч. 


\subsection{2. ТИП П2 - мотивисана именица с краткосилазним на првом слогу} (префиксу)

1.2.2.1. Преглед по префиксима:

\begin{tabular}{|c|c|}
\hline над-* & нӓдлуга̄p : лу̀zа̄p \\
\hline не- & нёмора̄л: мо̀ра̄л, нёуспех : у̀спех, нёвре̄ме : вре́ме \\
\hline по-* & пӧмеђа: мѐђа \\
\hline под- & 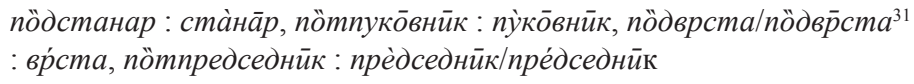 \\
\hline пра- & прӓдомовина: до̀мовина, прӓэсивотињ $:$ :сиво̀тињ, прӓунук : у̀нук (.... $)^{32}$ \\
\hline пред- & 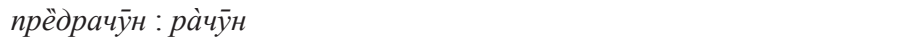 \\
\hline ca- & сӓучеснйк : у̀чеснйк \\
\hline cy- & сӱстана̄p : ста̀на̄p \\
\hline
\end{tabular}

За префиксе означене звездицом (*) нема потврде у свим речницима: нӓдлуга̄р у РМС6 и ОР; пӧмеђа у РМС6 и ОР.

Исто важи за:

1) префикс над-: само у РМС6: нӓтпоручнйк : по̀ручнйк;

2) префикс не-: РМС6 и ОР: нёпрола̄з : про̀лаз/про́лаз ${ }^{33}$; само у ОР: нёдруиштво : дру́штво;

3) префикс по-: РМС6 и ОР: пӧткомо̄рнйк : ко̀мо̄рнӣк;

4) префикс пра-: РМС6 и ОР: прӓстарина ${ }^{34}$ : старѝна, прӓбӣће : би́ће;

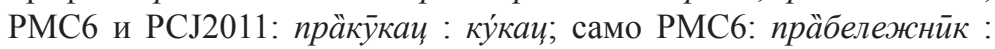
бѐлежнйк;

5) префикс ca-: само у PMC6: cäбйћe : бúћe.

Поред њих, у следећим примерима речници се не слажу око места узлазног акцента мотивне речи, али је тип свакако П2: РМС6 прёдгово̄рнйк : го̀воррнйк/говоेрнйк, а ОР и РСЈ2011 прёдговоррнйк : го̀ворннйк; РМС6 сӓгово̄рнйк

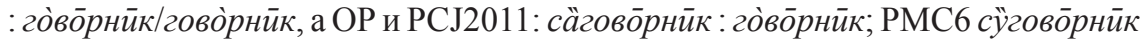

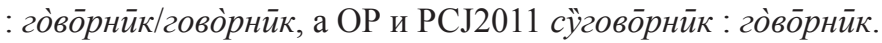

1.2.2.2. Тип који је потврда творбено мотивисаног акцента. Алтернација јасно подразумева да се неутралише узлазни акценат мотивне речи, било да неутрализација представља једино дејство творбеног модела, при чему се затим реализује немаркирани силазни акценат на првом слогу, било да је она исход конкуренције између очувања акцента мотивне речи и тежње префикса да привуче високи тон (в. т. 1.1.1.2).

\footnotetext{
${ }^{31}$ РСЈ2011 само обрнутим редоследом.

${ }^{32}$ Овде и прӓунука и прӓунуче ако нису суфиксацијом од праунук, и прӓунуча̄д, осим ако је суфиксацијом од прӓунуче.

${ }^{33}$ ОР само за мотивну реч обрнут редослед.

${ }^{34}$ Осим ако је суфиксацијом од прастар.
} 
Реч је о мање заступљеном типу у речницима у односу на претходни, са изузетком једино префикса $n p a-$, који чешће иде према овом типу.

1.2.2.3. Тврдили бисмо да су у два случаја сасвим обични (можда и обичнији од датих решења по П2) ликови са секундарним акцентом, с два акцента или по типу М0:

1) код префикса међу-: мёђуйгра, поред у ОР већ датог међуйгра (уп. т. 1.1.1.3);

2) код префикса пра-: прӓро̀дитељ (поред праро̀дтељ, које дају ОР и РСЈ2011), прӓко̀лёвка (поред у ОР датог прако̀лёвка), нарочито када је мотивна реч дужа - уместо нпр. прӓдомовина, прӓживотиња, прӓпосто̄јбина, пра̄производња/прӓпроизво̄дња, прӓсупстанција, обичније нам је (осим по М0): прӓдо̀мовина, прӓжсивотина, прӓпо̀сто̄јбина, прӓпроизво̀дња/прӓпроизво́дња, прӓсупста̀нщија и сл.

\subsection{3. ТИП П3 - мотивисана именица с краткоузлазним испред акцентованог слога мотивне речи}

1.2.3.1. Преглед по префиксима:

\begin{tabular}{|l|l|}
\hline до- & доручак : ру́чак \\
\hline за-* & за̀nапак : па́nак \\
\hline по-* & по̀сестра : сѐстра \\
\hline су- & су̀међа $:$ мѐђа \\
\hline
\end{tabular}

За префиксе означене звездицом (*) нема потврде у свим речницима: за̀nanaк само у РMC6, а nòcecmpa у РМС6 и ОР.

1.2.3.2. Корпус показује да у префиксалној творби именица с мотивном речју на којој је узлазни акценат, суштински, могу функционисати два процеса: акценат се чува на слогу мотивне речи или се он неутрализује и као резултат се јавља краткосилазни на првом слогу, тј. слогу префикса.

Малобројни акценатски ликови које убрајамо у овај тип су, у извесном смислу, изненађење. Њихов акценат се не може сматрати очекиваним резултатом процеса̂ до сада приказаних творбених модела у префиксацији, нити се он, с друге стране, може објаснити фонолошким факторима у одсуству деловања интерфејса с творбом речи.

Рекли бисмо да ови ликови уопште нису добијени акценатском алтернацијом типичном за префиксацију. Претпостављамо да је на њихово настајање могло утицати угледање на друге примере, фонолошки и творбено сличне.

1) Акценат лексема доручак и за̀nапак могао се формирати аналогијом према типичном акценту тросложних именица с непостојаним /a/ на последњем затвореном слогу које су настале префиксално-суфиксалном творбом са суфиксом -(a)к, уп. доेратак, дозлавак, доземак, докрајак, дорамак, односно за̀брежак, за̀крајак, за̀щепак, за̀вратак, за̀ушак. Слично су на пос- 
танак лика са̀кривац могла деловати префиксално-суфиксална образовања на -(а)u, уп. за̀брдаи, за̀мораи, по̀мораи, по̀дгораи, по̀дгрлаи, по̀дрепаи, прѝгорац, прйселащ, у̀згорач и сл.

2) Ликови по̀сестра и по̀ћћерка могли су се угледати на семантички врло блиске по̀рат и по̀ма̄јка (оба добијена фонолошки, метатонијским преношењем, в. П1).

\section{3. Посебни случајеви}

1.3.1. Тип М1 - у мотивисаној именици силазни акценат остаје на акцентованом слогу мотивне речи, али постаје узлазни

Једини пример око којег у речницима нема слагања је истовремено и онај који срећемо само у једном од њих, РМС6: подза́ставнйк : заิставнйк/ зӓставнӣ⿲彳 $\kappa^{35}$.

Овакви односи вероватно нису резултат акценатске алтернације која се системски одвија у четвороакценатским системима, него су настали као резултат интервенција лексикографа у циљу адаптације облика нормираном.

Наведени пример јесте једини за који се на основу решења у самом речнику може извести искључиво наведено објашњење алтернације. Акценат мотивисане именице не споримо. Међутим, за разлику од других сличних примера (в. т. 4.1.2.1), са̂м однос тумачимо као последицу грешке лексикографа, за којег верујемо да је изоставио лик за́ста̄внйк (који пак дају и ОР и РСЈ2011) и очекивана решења с краткосилазним (ликови пӧдза̄ставнйк/ пӧдзаставнйк нам свакако изгледају прихватљиво) и/или с краткоузлазним на првом слогу, што би уједначило одредницу; овако смо добили решење које не одговара систему и за које бисмо притом рекли да не прати стварну ситуацију.

\subsection{2. Тип П4 - мотивна именица са силазним, а мотивисана с дугоузлазним акцентом на слогу испред акцентованог слога мотивне речи (префиксу)}

Налазимо само два примера, оба дублетна - око једног речници дају различита решења (pácnon : nön, в. т. 7), а другог нема у РCJ2011 - то је (прӥзйд/)при́зид : зйд.

За разлику од суфикса, од којих неки могу носити постакценатску дужину као своје стално обележје, слогови изолованих префикса по природи су увек кратки, што се прегледом свих типова може потврдити и да начелно остаје и након префиксације именица (в. т. 2). То нам сугерише да промена квантитета тог слога није примарни производ прозодијског процеса који је својствен префиксацији.

У овом тренутку можемо понудити једно могуће објашњење. Наиме, дугоузлазни у оваквим примерима може бити производ угледања на акценат именица истоветне прозодијске структуре које припадају сасвим другом

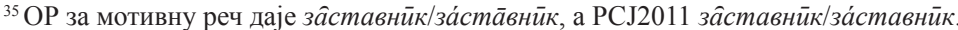


творбеном типу - творбу двосложних именица са затвореним другим слогом нултим суфиксом од глаголске основе, уп. присту́nuти : при́стуn, разво̀зити : ра́звоз и сл. образовања.

\subsection{3. Тип М2 - силазни акценат мотивне именице остаје на истом,} сада унутрашњем, слогу мотивисане

За једини пример овог типа, пронађен у РСЈ2011, речници се не слажу: међустӓница(/мёђустанийа) : стӓница (в. т. 7 за друга лексикографска решења).

Лик мёђустаница разматрамо у т. 4.1.2.1. За међустӓница пак нисмо сигурни, и то не због силазног унутар речи - сматрамо га присутним у узусу и да га у оваквим случајевима треба прихватити (уп. Дешић 2018: 181) - већ зато што бисмо рекли да се код префиксације именица са међу-у случају чувања акцента на мотивној речи ипак јавља и, макар секундарни, акценат на првом слогу, што се пак мора утврдити експерименталним истраживањима.

\subsection{4. Тип М3 - наспрам узлазног акцента мотивне именице,} на истом, сада унутрашњем, слогу мотивисане јавља се силазни аценат

Једини забележени пример налази се само у ОР: противпрӥтӣсак : прӥтиисак/прѝтисак.

Паралелно с примером међустӓница у претходној тачки, реалније нам је прӧтивпрӥтйсак, при чему акценат на првом слогу може бити секундарни (в. т. 1.1.1.3).

Лексикограф највероватније није хтео дати однос противпрӥтӣсак : прѝтисак - јер кориговање квалитета у корист силазног овде није нити у складу са системом, нити је блиско важећој акценатској норми - већ је, по свему судећи, само испустио лик противпрйтисак. У складу с претходним, њему бисмо придружили и прӧтивпрѝтисак, где акценат на првом слогу можда може бити и секундарни.

\subsection{5. Остали односи}

1.3.5.1. У речницима налазимо акценатске односе између мотивних и њима мотивисаних именица које се не могу једноставно уклопити у претходно изнете типове, првенствено, рекло би се, јер представљају производ недоследности у обради у оквиру истог речника или случајне омашке.

1.3.5.2. У прву групу сврставамо однос међустӓница/мёђустаница : cmäница/ста̀ница ${ }^{36}$ из ОР (РМС6 даје овај однос по П0/M1, а РСЈ2011 по П0/М2). Рекли бисмо да је ово, фактички, однос П0/М2, на који је додат лик

\footnotetext{
${ }^{36}$ Други лик мотивне речи у загради.
} 
мотивне речи ста̀ница , при чему лексикограф није даље доследно испратио и акцентовање мотивисане именице.

1.3.5.3. Другу групу представљају обичне недоследности.

1) Код префикса без- РМС6 бележи бешчо̀вештво/бешчове́штво : чо̀вештво, где недостаје чове́штво да би однос био М0 (ОР у т. 1.3.5.5; РСЈ2011 нема мотивисану именицу, док је мотивна исто акцентована).

2) Код префикса не- у РМС6 налазимо неваспита́не : васnѝmāıel

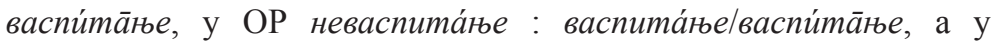
РСЈ2011 неваспита́не/неваспи́mārbe : васпита́rве; ови парови би требало да иду по М0.

3) Код префикса пра-, PMС6 и РСЈ2011 имају прӓстановнӣк/ прастано̀внйк : стано̀внйк/ста̀но̄внйк. Ово је требало да буде М0/П2 однос (ОР даје само по М0), али је заборављен лик праста̀но̄внйк.

1.3.5.4. За примере из ове групе чини нам се да је реч о обичним омашкама, можда и штампарским грешкама:

1) префикс не-: у PMC6 непо̀cmojāıe/непосто̀jārse : nócmojārbel nосто̀jа̄ње, које би навероватније требало да иде по М0 (у РСJ2011 јесте M0, а у ОР такође, само што он додаје постоја́ғье и непостоја́rbe);

2) префикс пре-: у РМС6 препро̀изводња/препроизво́дња: произво́дња/ произво̀дња, а у ОР препро̀изводња/препроизво́дња: произво̀дњаl произво́дња, што би такође требало по М0 (РСЈ2011 нема мотивисану именицу $\left.{ }^{37}\right)$;

3) префикс против-: РСЈ2011: противдо́каз/прӧтивдока̄з : до́каз/ домказ, где је дужина вероватно требало да иде на претпоследњи слог као чување квантитета према до́каз (РМС6 и ОР дају само по $\mathrm{M} 0)$.

1.3.5.5. Коначно, посебно издвајамо обраду именица бешчовештво и нечовештво ${ }^{38}$ у ОР - бёшчовештво/бешчове́штво : чове́штво/чо̀вештво и нёчовештво/нечове́штво : чове́штво/чо̀вештво највероватније представљају укрштене односе М0 и П2 (РМС6 даје по М0/П2; РСЈ2011 нема мотивисану именицу $\left.{ }^{39}\right)$.

\section{4. Разлике у лексикографској обради}

Из размимоилажења лексикографа̂ у акценатским решењима за одређени број примера (који није занемарљив) проистиче и неусаглашеност око тога којим би од већ изложених типова акценатских алтернација они припадали (преглед је дат у т. 6).

\footnotetext{
${ }^{37}$ РСЈ2011 за мотивну реч даје произво̀љъа/произво́дња.

${ }^{38}$ Друга се, додуше може тумачити као резултат суфиксације од лексеме нечовек.

39 За РСЈ2011 има само чо̀вештво.
} 


\section{2. О квантитету слогова у префиксалној творби именица}

2.0. У овом одељку размотрићемо квантитетске алтернације између мотивне и мотивисане речи у префиксацији именица.

2.1. Преглед анализиране грађе показује да је општи принцип очување квантитета мотивне речи. Притом код дублета̂ (в. т. 4) услед недоследности каткад долази до укрштања:

1) PМС6 и РСJ2011: непа̀жња/непа́жња: па́жња/па̀жња;

2) ОР и РСЈ2011: нёдоба/нёдобба и прӓдоба/прӓдобба према добба/дӧба;

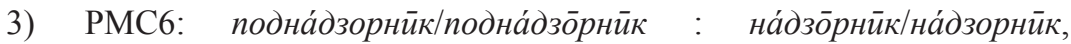
прӓпроизводња/прӓпроизво̄дња : произво́дња/произво̀дња, прёдра̄cyда/nрёдрасуда : päcyда/pâcyда, изгледа и у нёскла̄д/нѐсклад : склӓд/склаิд;

4) PCJ2011: нена́сиље/нена́сӣље : нена́сӣље/нена́сиље.

2.2. Одступања се такође често јављају као резултат недоследности:

1) скраћивање акцентованог слога мотивне речи:

а) сва три речника: РМС6 и ОР нёбораичнёборац : бо́рай/бо̀раи, а PCJ2011 нёбораи/нёбораи : бо́раи, пӧдврста/пӧдвр̄ста ${ }^{40}$ : вр́ста, пӧтпредседнйк : прѐдседнйк/пре́дседнйк, РМС6 и ОР сӓборач : бо́раи/боррай ${ }^{41}$, а РСJ2011 сӓбораи : бо́рач;

б) РМС6 и ОР: нёпролаз : про̀лаз/про́лаз, пӧдшеф/по̀дшеф ${ }^{42}$ : шёф/ шеิф, прёдспис : сnиิс/сnӥс, преду̀пис : у̀пис/ӥпис, РМС6 сӓбораи : бо́раи/бо̀раu, а ОР и РСJ2011 сӓбораи : бо́раu;

в) РМС6 и РСЈ2011: међупро́стор : про́стор/nрòcmop;

г) ОР и РСЈ2011: нѐсклад/нёсклад ${ }^{43}$ : склӓд/склаิд;

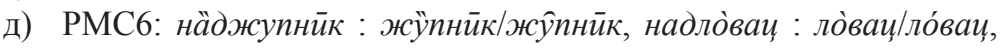
нёдоба: доба /дӧба,

ђ) РСЈ2011: међуу̀сев : у̀сев/у́сев, прӓжитељ : жи́тељ/жӥтељ, предна́чрт/прёдначрт : на́црт, преду̀слов/преду́слов/прёдуслов

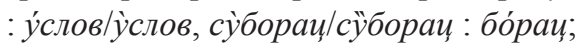

2) скраћивање постакценатског слога мотивне речи: у РМС6 нѐпле-

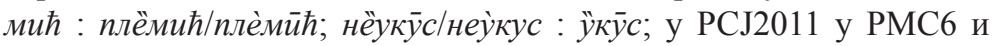
РСЈ2011 нёспоразум : спӧразӯм, прӓстановнйк/прастано̀внйк : стано̀внйк/ста̀но̄внйк;

3) дуљење акцентованог слога мотивне речи:

а) у РМС6: међупро́стор : про́стор/про̀стор, на̀дса̄тнйк : сӓтнйк/ саิтнӣк, подна́тпис : на́тпис/на̀тпис, пражи́тељ : жѝтељ/ житељ, прёдгово̄рнӣк:го̀воррнйк/гово̀рнӣк, противдо́каз : до́каз/

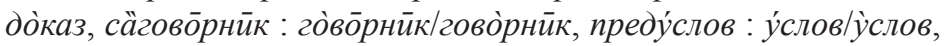

\footnotetext{
${ }^{40}$ РСЈ2011 само обрнутим редоследом.

${ }^{41}$ ОР други у загради.

${ }^{42}$ ОР само обрнутим редоследом.

${ }^{43}$ РС 2011 само обрнутим редоследом.
} 


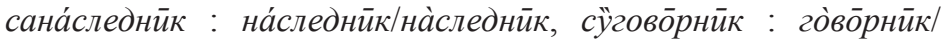

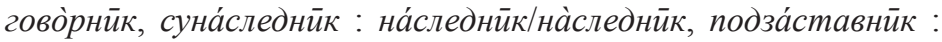
заิставнйк/зӓставнӣк, преду́слов : у́слов/уेслов;

б) у ОР: противдо́каз : до́каз/до̀каз;

4) дуљење постакценатског слога мотивне речи:

а) у РМС6: неса̀zла̄cje : càzла̄cje/càzласje;

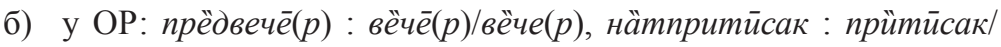
приेтисак, противпрӥтӣсак : прӥтӣсак/прѝтисак;

в) у РCJ2011: нӓтпритӣсак : прӥтӣсак/прѝтисак;

2.3. У следећим примерима изгледа да је реч о случајним омашкама, можда и штампарским:

1) дуљење постакценатског слога мотивне речи:

а) у РМС6 и ОР нёпрола̄з : про̀лаз/про́лаз, нёпрола̄з : про̀лаз/ про́лаз;

б) у РСЈ2011: противдо́каз/прӧтивдока̄з : до́каз/доेказ;

2) скраћивањеакцентованогслогамотивнеречи:у РМС6непо̀стоја̄не/ непосто̀jāıe : nócmojārbe/nocmòjārbe.

2.4. Квантитетска алтернација у неким случајевима би могла бити утицај угледања на друге творбене начине и моделе (в. т. 1.2.3; 1.3.2):

1) скраћивање дугог акцентованог слога мотивне речи:

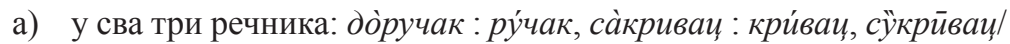
су̀криваи : кри́ваи;

б) у РМС6 за̀nапак : па́пак; прѝмозак : мӧзак/моิзак;

в) у РСЈ2011 нёбораи/нёбораи : бо́раџ, нёсклад/нѐсклад: склӓд/ склаิд, су̀бораи/сйбораи : бо́раи;

2) дуг слог префикса:

а) у РМС6 и ОР: прӥзйд/при́зид : зйд,

б) y PMC6: pàcnon/pácnon : nön.

2.5. Приметно је да у очигледним случајевима метатонијског преношења нема двосложних мотивисаних именица с краткоузлазним акцентом и дужином:

1) у РМС6: нёскла̄д/нѐсклад : склӓд/склаิд, по̀дмост : моิст, по̀дрок : роิк/рӧк, пӧдшеф/по̀дшеф : шёф/шерф, прйглас : глаิс;

2) у ОР: нёро̄д/нѐрод : роิд, нѐсклад/нёсклад : склӓд/склаิд, по̀дрок : рокк, по̀дшеф/пӧдшеф : шёф/шеิф, прйглас : глаิс.

РСЈ2011: нёсклад/нѐсклад : склӓд/склаิд,

То би могло бити јер прозодијски систем избегава формирање акценатске парадигме мла̀dй : млади́ћa, највероватније јер би то системски нарушило акценатске парадигме мотивних речи, да се не би створили компликовани односи моิст : мӧста : по̀дмо̄сm : подмо́ста и сл. 
2.6. Слог с непостојаним /a/ у једном примеру постаје дуг: у РМС6 бѐздан/бёздарн : днӧ.

2.7. На крају, само као констатација: сва три речника (сасвим оправдано) бележе скраћивање акцентованог слога мотивне речи у са̀nутнйк : пуิтнйк и са̀раднйк : раิднйк.

\section{3. Творбена гнезда}

3.0. У овом делу рада примарни критеријум за класификацију јесу мотивне речи које се јављају у две лексеме или више њих, како би се најјасније показало ступа ли у префиксацији именица иста мотивна именица у различите акценатске алтернације с њоме мотивисаним именицама у зависности од префикса који се додаје, тј. могу ли на акценатске алтернације у префиксацији именица утицати искључиво префикси.

3.1. Мотивна реч има силазни акценат:

1) и ступа у исту акценатску алтернацију:

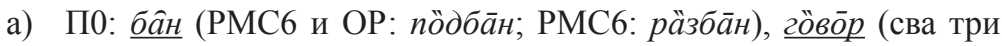
речника: пӧгово̄p, прёдгово̄p), дӧба/добба ${ }^{44}$ (сва три речника: прӓдоба/nрӓдоба; РМС6 нёдоба, а РСЈ2011 и ОР и нёдоба), друิг

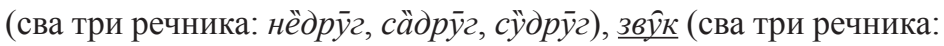

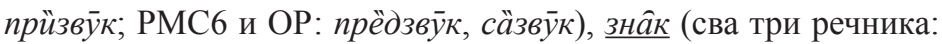

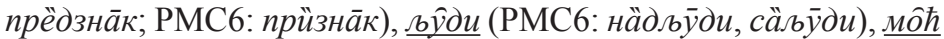

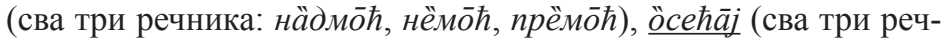

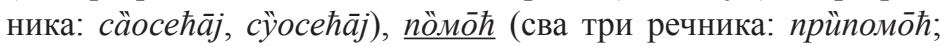
РМС6 и ОР: бёспомо̄ћ), прӥвреда (РСЈ2011 и ОР: нёпривреда; ОР: вӓнпривреда), pâd (сва три речника: нёра̄д; РМС6: прӥра̄д), све̂ст (сва три речника: бёсвёст, нёсвёст, пӧдсвёст, прёдсвёст),

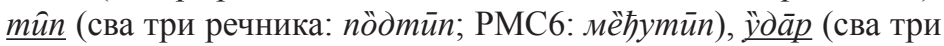
речника: прӧтивудар ; РМС6 и ОР: прёдуда̄p);

б) П1: брӓm (сва три речника: нѐбрат, càбрат; РМС6 и ОР: поббрат), брйга (сва три речника: бѐзбрига, нѐбрига), раิднйк

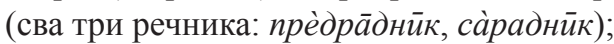

2) и ступа у више акценатских алтернација:

а) П0 и П1: броิj (сва три речника: бёзбро̄j/бѐзбро̄j; ОР: мёђубро̄j), глаิс (РМС6 и ОР: бёзгла̄с, приेглас), јёло (сва три речника: прёдјело; сва три речника: нејјело; РМС6 и РСЈ2011: међу̀јело), кра̂љ (сва три речника: ра̄скра̄љ/ра̀скра̄љ; РМС6 и ОР:

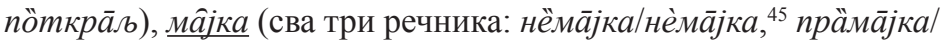
пра̀ма̄jка; РМС6 и ОР по̀ма̄јка, а РСЈ2011 само пӧма̄jка), мӓти (сва три речника: по̀мати, прӓмати), мйло̄ст (сва три речника: су̀мило̄ст/сӱмило̄ст; РМС6 са̀мило̄сm/сӓмило̄сm, а РСЈ2011

\footnotetext{
${ }^{44}$ РСЈ2011 и ОР само обрнут редослед.

${ }^{45}$ РСЈ2011 и ОР само обрнут редослед
} 
и ОР само са̀мило̄сm), смйсаo (РМС6 бёсмйсао, а РСЈ2011 и ОР дају и бѐсмйсао; РМС6 и ОР: нѐсмйсао), шиӓв (РМС6 и ОР: по̀дшав; РМС6 прйшав, а ОР прѝшав), шйма̄p (РМС6 и ОР: нӓдшума̄p; РМС6 по̀дшума̄p, а ОР и пӧдшума̄p);

б) П0, П1 и П4: nön (PMC6 нàmnon/нämnon, а РСJ2011 само hàmnon; $\mathrm{PCM6}$ и $\mathrm{PCJ} 2011$ pácnon/päcnon, a $\mathrm{OP}$ pàcnon/pácnon).

3.2. Мотивна реч има узлазни акценат:

1) и ступа у исту акценатску алтернацију:

а) МО: бѐседнйк (сва три речника: сабѐседнйк, субѐседнйк), де́jство (сва три речника: саде́јство; РМС6: противде́јство), nódне (сва три речника: допо́дне, попо́дне, препо́дне), по́седнйкl

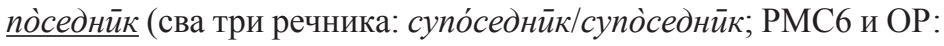

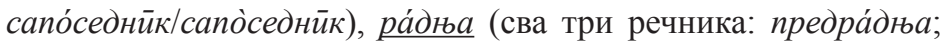
PMC6: противра́дња), сезо́на (сва три речника: предсезо́на; РСЈ2011 и ОР: вансезо́на), срѐдство (ОР: међусрѐдство, противсрѐдство), у̀дарац (сва три речника: противу̀даращ; PMC6 и ОР: предудараи), у̀читељ (РМС6 и ОР: подуччтељ; PMC6: наду̀читељ), на́следнйк/на̀следнйк ${ }^{46}$ (РМС6 и РСJ2011

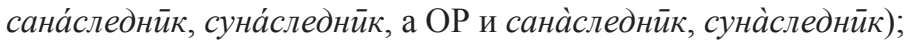

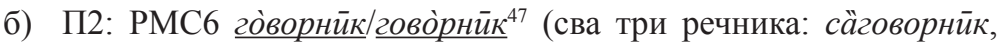

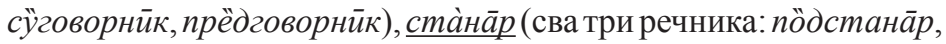
сӱстана̄p);

2) и ступа у више акценатских алтернација:

а) М0 и П2: бѐлежнйк (РМС6 и ОР: подбѐлежнйк; РМС6: прӓбележнйк), би́ће (сва три речника: неби́ће; РМС6 и РСЈ2011: cäбйћe, РМС6 и ОР: прӓбӣће), вре́ме (сва три реч-

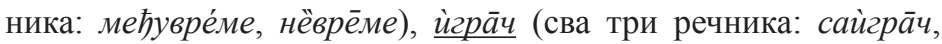
cyѝгра̄ч/сӱнгра̄ч; РМС6 и ОР: неиेгра̄ч), жйвот (РМС6 и PCJ2011: прёдживот, а ОР на првом месту и преджѝвот; ОР: сужѝвот/сўживот), ѝсто̄рија (сва три речника: прӓисто̄рија) nрайсто̄puja ${ }^{48}$, прёисто̄puja/nрейсто̄рuја; РМС6 и РСЈ2011 предѝсто̄puја/прёдисто̄рија, а ОР само предѝсторрија), на́слов (сва три речника: подна́слов; РМС6 нӓдна̄слов, а ОР и РСЈ2011 надна́слов и нӓдна̄слов у загради), о̀тац (РМС6 нёотаи, а ОР неоттаu; РМС6 и РСЈ2011 nрӓотаu, а ОР и праоттаи),

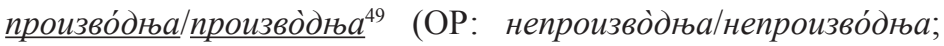
РМС6 прӓпроизводња/прӓпроизво̄дња, а ОР прапроизво̀юаа прапроизво́дъа; РМС6 препро̀изодња/препроизво́дња, а ОР даје препроизво́дња/препроизво̀дња), Сло̀вён (сва три речника: Прӓсловён/Праслоेвён; РСЈ2011 и ОР: несло̀вён), тѐрён (сва

\footnotetext{
${ }^{46}$ РС 2011 само први лик.

${ }^{47}$ РСЈ2011 и ОР само први лик.

${ }^{48}$ ОР само обрнутим редоследом.

${ }^{49} \mathrm{OP}$ и РСЈ2011 само обрнутим редоследом.
} 
три речника: сӱтере̄н/сутѐре̄н ${ }^{50}$; РМС6 и ОР: предтѐре̄н), фа́за (РСЈ2011 и ОР: међуфа́за; РСЈ2011 претфáза/nрётфа̄за, а ОР само претфа́за)

б) П2 и П3: мѐђа (сва три речника: су̀међа; РМС6 и ОР: пӧмеђа);

в) П2, П3 и М0: РМС6 бópau/бòpaú ${ }^{51}$ (сва три речника: нёбораи/ нёборац, сӓбораи; РМС6 и ОР субо́раия/суборраи, а РСJ2011 су̀бораи/сӱбораи); кри́ваи (сва три речника: сӱкрйваи/су̀криващ, ${ }^{52}$ РМС6 и РСЈ2011 са̀криваu, а ОР и сакри́ваu).

3.3. Мотивна реч је дублет, са силазним/узлазним акцентом:

1) све мотивисане именице су с краткосилазним на префиксу (П0/ П2): $\underline{\text { човек }} /$ чӧвек $^{53}$ (сва три речника: нёчовек, прӓчовек, рӓччовек; РМС6 и ОР: нӓтчовек; РМС6: пӧтчовек);

2) посебно: према прйтӣсак/прйтисак РСЈ2011 и ОР дају нӓтпритӣсак, а ОР противпрӥтӣсак;

3.4. Речници се не слажу око квалитета мотивне речи:

1) РМС6 и ОР: грӱпа, а РСЈ2011 даје и гру̀na - OP: прѐдгрупа। прёдгрупа, РМС6 и ОР по̀дгрупа, а РС 2011 и подгру̀nа;

2) РМС6 и ОР $\underline{\text { ùpa }}$, а РСЈ2011 у загради и йгра - сва три речника: прёдигра, ОР: противѝгра, РМС6 мёђуигра, а РСЈ2011 и ОР и међуйгра;

3) РМС6 и РСЈ2011 по̀ручнӣк, а ОР и пӧручнйк - сва три речника: пӧтпоручнйк, РМС6 и ОР: нӓтпоручнӣк;

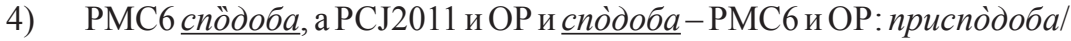
прйсподоба ${ }^{54}$, РМС6 прйсподоба, а ОР и приспо̀оба.

3.5. На основу акценатских алтернација у приказаним творбеним гнездима, могу се извести следећи општији закључци везани за акценат у префиксацији именица:

1) мотивној речи са силазним акцентом најчешће одговара и мотивисана реч са краткосилазним на првом слогу, независно од префикса;

2) мотивна реч са узлазним акцентом најчешће задржава свој акценат у мотивисаној речи, независно од префикса;

3) активирање различитих акценатских алтернација између једне мотивне речи и њоме мотивисаних речи не може се корелирати с присуством конкретних префикса.

\footnotetext{
${ }^{50}$ ОР само обрнутим редоследом.

${ }^{51}$ ОР други у загради, а РСЈ2011 га нема.

${ }^{52}$ ОР само обрнутим редоследом.

${ }^{53}$ ОР и РСЈ2011 само обрнутим редоследом.

${ }^{54} \mathrm{OP}$ само обрнутим редоследом.
} 


\section{4. Акценатска дублетност у префиксалној творби именица}

\section{1. Дублетност по месту и квалитету акиуента}

4.1.1. Постоје четири односа варијантности по месту и квалитету акцента за која је потврђен макар један пример у сва три речника. Наводимо их редом према броју забележених примера, од најзаступљенијег до најмање заступљеног: П0/П1, М0/П2, П0/П2 и П2/П3.

4.1.1.1. Примери за П0/П1:

1) у сва три речника:

- префикс без-: бёзбро̄j/бѐзбро̄j : броิj, бёскра̄j/бѐскра̄j : краิj;

- префикс међу: мёђуспрат/међу̀спрат : спрӓт;

- префикс не-: нёистина/нѐистина : ӥстина, нѐслога/нёслога ${ }^{55}$ : слӧга, нёма̄јка/нѐма̄јка ${ }^{56}$ : маิјка;

- префикс под-: пӧдшеф/по̀дшеф ${ }^{57}$ : шёф/шехф;

- префикс пра-: прӓбаба/пра̀баба : бӓба, прӓдед(а)/пра̀дед(a) :

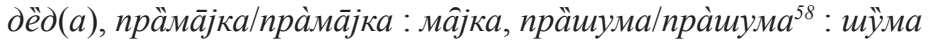

- префикс раз-: рӓскра̄љ/ра̀скра̄ль : краิљ;

- префикс су-: су̀мило̄ст/сймило̄ст : мйло̄ст;

2) само у РМС6: мёђупостаја/међу̀nостаја : nöстаја;

3) само у ОР: прѐдгрупа/nрёдгрупа : грйnа ${ }^{59}$.

И мёђуспрат и међу̀сnрат су нам даљи од реализације с два акцента мёђуспрӓт. С друге стране, поред мёђусло̄j тврдили бисмо да може и мёђуслоेj, док нам је међу̀сло̄j најдаље. Код два акцента у овим примерима, први може бити и секундарни (уп. т. 1.1.1.3).

4.1.1.2. Примери за М0/П2:

1) у сва три речника:

- префикс не-: непри́лика/нёпрйлика : при́лика;

- префикс под-: пӧджупа̄н/поджу̀па̄н : жу̀па̄н, пӧдофицйр/ nодофѝчйр : офѝuйp;

- префикс пра-: Прӓсловён/Прасло̀вён : Сло̀вён, прӓста̄њее праста́њье : ста́њье, прӓузрок/прау̀зрок : у̀зрок, прӓисто̄рија/ прайсто̄рија ${ }^{60}$ : ѝсто̄рија, пра̄поче̄так/прапоче́так ${ }^{61}$ : поче́так;

- префикс пре- 1: прёисто̄рија/преиेсто̄рија ${ }^{62}$ : ѝсто̄рија, прёобйле/преоббйље $e^{63}$ : обйьье;

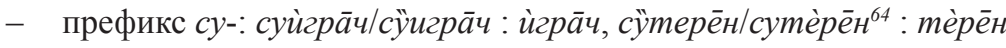

\footnotetext{
${ }^{55}$ РСЈ2011 префиксал обрнутим редоследом

${ }^{56}$ ОР и РСЈ2011 само обрнутим редоследом.

${ }^{57}$ ОР само префиксале обрнутим редоследом. РСЈ2011 за мотивну реч има само шёф

${ }^{58}$ ОР само обрнутим редоследом.

${ }^{59}$ РСЈ2011 за мотивну реч даје и грӱпа.

${ }^{60} \mathrm{OP}$ само обрнутим редоследом.

${ }^{61}$ ОР само обрнутим редоследом.

${ }^{62} \mathrm{OP}$ само обрнутим редоследом.

${ }^{63}$ ОР само обрнутим редоследом.

${ }^{64} \mathrm{OP}$ само обрнутим редоследом.
} 
2) само у РМС6: нёугодба/неу̀годба: у̀годба;

3) само у ОР: сужѝвот/сйживот : жиेвот.

За наведене случајеве напомене би биле истоветне онима у т. 1.2.1.3-5 и $1.2 .2 .3-4$.

4.1.1.3. Примери за $\underline{\Pi 0 / \Pi 2:}$

1) сва три речника: према чо̀век/чӧвек ${ }^{65}-$ нӓтчовек, нёчовек, прӓчовек и рӓшчовек;

2) РМС6 и пӧтчовек;

3) ОР и РСЈ2011: нӓтпритӣсак : прӥтӣсак/прѝтисак;

4) само ОР: нёкњижеевнӣк : књѝжевениик/књйжеевнйк.

Коментаре за типове П0 и П2 дали смо у т. 1.1.1.2-3, односно 1.2.2.3-4. Тврдили бисмо да је према књѝжёвнйк обично и некњѝжёвнйк.

4.1.1.4. Једини пример П2/П3 потврђен у сва три речника је сӱкрйваия/ су̀кривай : кри́ваu. За њега важе коментари већ изнети у т. 1.2.2.3-4 и 1.2.3.3.

4.1.2. За три врсте дублетних односа нема потврде у свим речницима: П0/M1, M0/M1, М2/M3 и П0/M0/M1/M2.

4.1.2.1. За дублетност П0/M1 проналазимо три примера, али само у РМС6, док ОР и РСЈ2011 дају друга решења:

\begin{tabular}{|c|c|c|c|}
\hline & PMC6 & OP & PCJ2011 \\
\hline међу- & $\begin{array}{l}\text { мёђустанииа/међуста̀нииа: } \\
\text { стӓнийа }\end{array}$ & (т. 1.3.5.2) & (П0/M2) \\
\hline \multirow{2}{*}{ не- } & 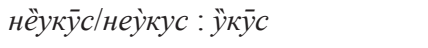 & \multicolumn{2}{|c|}{ (П0) } \\
\hline & неспо̀доба/нёсподоба : спӧдоба & (П0/M0/M1/M2) & l \\
\hline
\end{tabular}

Став према алтернацији M1 изнели смо у т. 1.3.1. Код тамонаведеног примера је, изгледа, дошло до омашке у акцентовању одреднице, а може се рећи да исто важи и у овим случајевима, будући да ОР даје и ста̀ница, додуше у загради, а ОР и РСЈ2011 наводе и спо̀оба.

Лик мёђустанииа нам, иако лексикограф доследно прати тип П0 да би неутралисао силазни ван првог слога, изгледа као неадекватно решење. Изгледнија су нам два акцента: мёђустӓнииза (по ОР и мёђуста̀нийа), од којих први може бити секундарни (уп. т. 1.1.1.3).

4.1.2.2. За дублетност М0/M1 потврду налазимо само у ОР: неу̀зданица

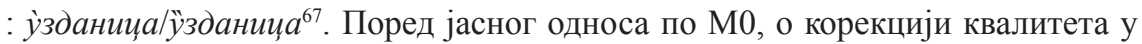
M1 говоримо у т. 1.3.1. Рекли бисмо пак да је наведени однос произашао из недоследности лексикографа.

\footnotetext{
${ }^{65}$ ОР и РСЈ2011 само мотивну реч обрнутим редоследом.

${ }^{66}$ ОР само обрнутим редоследом.

${ }^{67}$ РМС6 обрнут редослед ликова мотивне речи.
} 
4.1.2.3. За дублетност $\underline{\mathrm{M} 2 / \mathrm{M} 3}$ пример бележи само ОР: противпрӥтйсак : прӥтйсак/прѝтисак (в. т. 1.3.4).

4.1.2.4. Дублетност П0/M0/M1/M2 дају ОР и РСЈ2011 примером мёђукласа/међукла̀са : кла̀са/клӓса ${ }^{68}$. Може се претпоставити да наведени односи у узусу представљају заправо дублетност доследно по П0 и М0, али се укрштањем датих ликова код појединачних говорника могу реализовати и типови П2 и М1.

4.1.3. Одређене дублетне односе проналазимо само у примерима око којих речници дају различита решења (в. т. 6): П1/П3, П1/П3/M0/M1, П1/П4, П0/M1, П0/М2 и П0/П1/П2/П3. Прокоментарисаћемо два.

4.1.3.1. Дублетност П1/П3/M0/M1 присутна је у три примера, али међу речницима су неслагања око сваког од њих: ${ }^{69}$

\begin{tabular}{|c|c|c|c|}
\hline & PMC6 & OP & PCJ2011 \\
\hline не- & (П1/П3) & $\begin{array}{l}\text { нѐплемић/неплѐмӣћ: } \\
\text { плёмић/плѐмйћ }\end{array}$ & / \\
\hline \multirow{3}{*}{ под- } & (П1) & I & $\begin{array}{l}\text { nòdzpyna/noдгру̀na : гpÿnal } \\
\text { гpỳna }\end{array}$ \\
\hline & (M0) & (M0) & 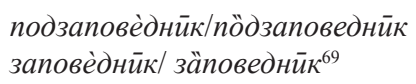 \\
\hline & (П1/П3) & $\begin{array}{l}\text { подо̀снова/по̀доснова : } \\
\text { оेснова/ӧснова }\end{array}$ & I \\
\hline
\end{tabular}

У избору датих решења за мотивисане и њихове мотивне именице код појединачних говорника могу се јавити алтернације и према П3 и M1, али претпостављамо да у узусу функционише алтернација или по П1 или по М0.

4.1.3.2. Пример за дублетност П0/М2 даје само РСЈ2011, док га остали речници акцентују другачије:

\begin{tabular}{|l|c|c|c|}
\hline & PMC6 & OP & PCJ2011 \\
\hline међу- & П0/M1 & т. 1.3.5.2 & мёђустаница/међустӓница : стӓницุа \\
\hline
\end{tabular}

Ликови су размотрени у т. 1.3.3, односно 4.1.2.1.

\footnotetext{
${ }^{68}$ РСЈ 2011 само мотивну реч обрнутим редоследом.

${ }^{69}$ Други лик мотивне речи је у загради.
} 
4.2. Дублетност по квантитету

4.2.1. У префиксалној творби именица, дублетност квантитета слогова мотивисане речи прати дублетност квантитета слогова мотивне речи (за тип М0 не наводимо мотивне речи):

1) сва три речника: прӓдоба/прӓдобба : дӧба/добба, прёдра̄суда/ прёдрасуда ${ }^{70}$ : рӓсуда/раิсуда, судр̀жављанин/судржа́вљанин, супо́седнӣк/супо̀седнӣк, супо́сед/супо̀сед ${ }^{71}$;

2) РМС6 и ОР: сапо́седнйк/сапо̀седнӣк, субо́райсубо̀раи, ОР прапроизводња/прапроизво́дња, а PMC6 прӓпроизводњаl прӓпроизво̄дња;

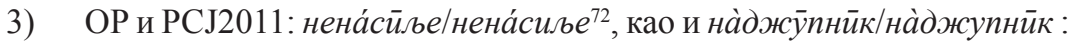

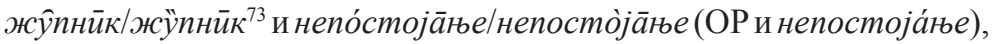
код којих у РМС6 увиђамо недоследност (в. т. 1.3.5.4; 2.2);

4) PМС6: нена́ука/нена̀ука;

5) ОР: на̀дсатнӣк/на̀дса̄тнӣк, непроизво̀дња/непроизво́дња, прау̀зор/nрайзор, као и примери у којима други речници показују недоследности: међупро́стор/међупро̀стор; међуу̀сев/ међуу́сев, прастано̀внӣк/праста̀но̄внӣк, преду́слов/преду̀слов, препроизво́дња/препроизво̀љь, сана́следнйк/сана̀следнйк, суна́следнйк/суна̀следнйк (в. т. 2.2);

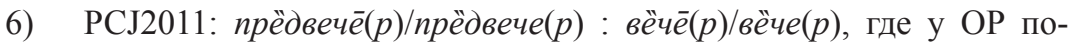
стоји недоследност (в. т. 2.2; у РМС6 ни мотивна ни мотивисана именица нису дублет).

4.2.2. Притом се дешава да долази до укрштања, на која смо указали у T. 2.1 .

${ }^{70} \mathrm{OP}$ и РСЈ2011 обрнутим редоследом.

${ }^{71}$ РСЈ2011 даје nо̀сед у загради.

${ }^{72}$ РС 2011 само обрнутим редоследом.

${ }^{73}$ РСЈ2011 само све обрнутим редоследом. 

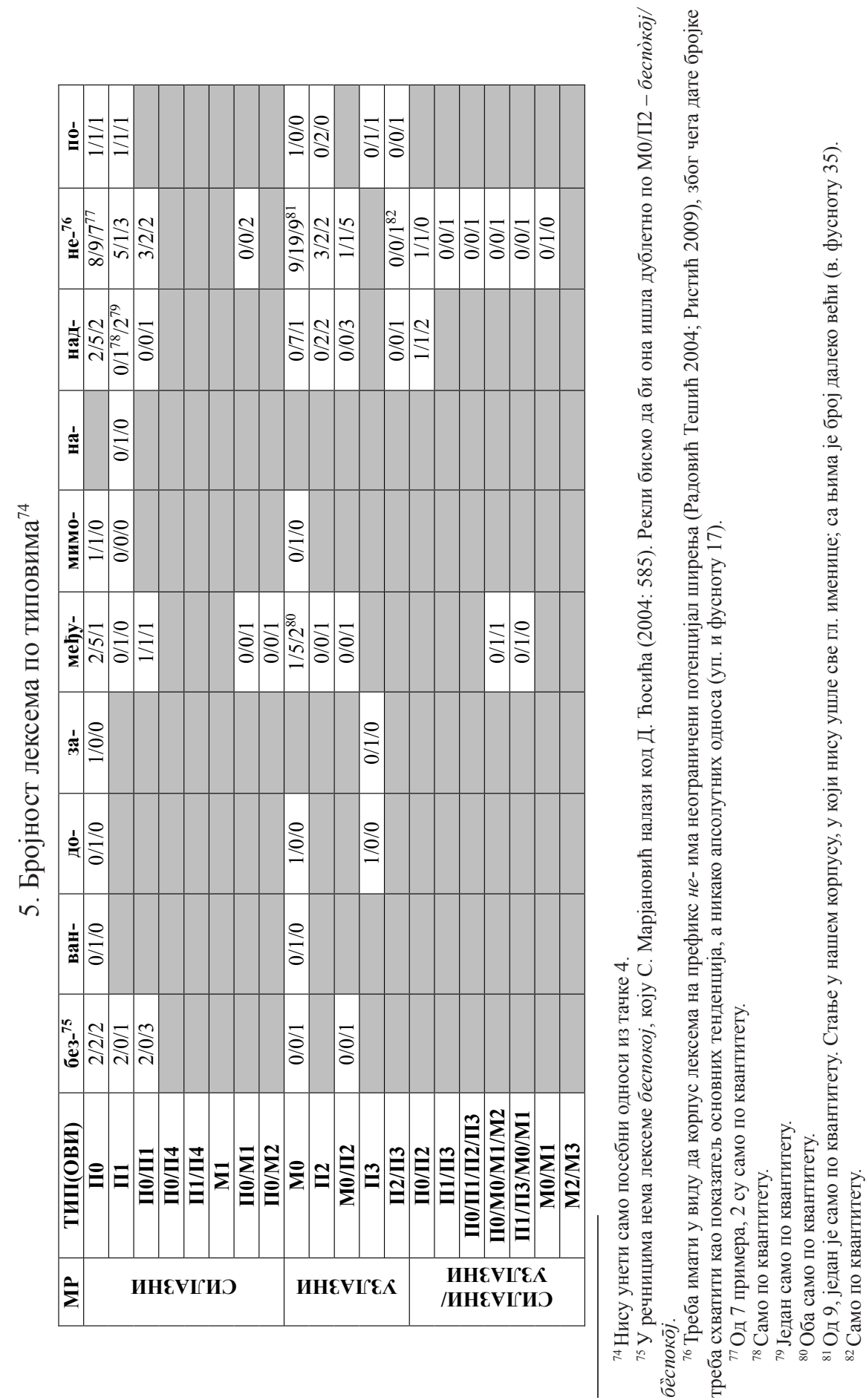
6. Преглед уочених неподударања у лексикографским решењима за место и квалитет акцента у префиксалној

творби именица

\begin{tabular}{|c|c|c|c|c|}
\hline \multirow{2}{*}{ ПРЕФ. } & \multirow{2}{*}{ ПРИМЕР } & \multicolumn{3}{|c|}{ ТИП АЛТЕРНАЦИЈЕ } \\
\hline & & PMC6 & OP & PCJ2011 \\
\hline \multirow{4}{*}{ без- } & бездан & П0/П1 & \multicolumn{2}{|r|}{$\Pi 1$} \\
\hline & бездно & П0 & П0/П1 & П0 \\
\hline & безизлаз & M0 & М0/П2 & l \\
\hline & бесмисао & П0 & \multicolumn{2}{|c|}{ П0/П1 } \\
\hline \multirow{3}{*}{ међу- } & међуигра & $\Pi 2$ & М0/П2 & П0/M0/M1/M2 \\
\hline & међуслој & l & П0/П1 & П0 \\
\hline & међустаница & П0/M1 & т. 1.3.5.2 & М2/П0 \\
\hline \multirow{7}{*}{ над- } & надбискуп & П0 & \multicolumn{2}{|c|}{$\Pi 0 / \Pi 2$} \\
\hline & наджупник & П0 & \multicolumn{2}{|r|}{$\Pi 1$} \\
\hline & надинжењер & П1/П3 & M0 & l \\
\hline & наднаслов & $\Pi 2$ & \multicolumn{2}{|c|}{ М0/П2 } \\
\hline & надстражар & $\Pi 2$ & М0/П2 & / \\
\hline & натконобар & П2/M0 & П0/П2 & l \\
\hline & Hamnon & \multicolumn{2}{|c|}{ П1/П0 } & $\Pi 1$ \\
\hline
\end{tabular}




\begin{tabular}{|c|c|c|c|c|}
\hline \multirow{15}{*}{ не- } & незгода & П1/П0 & П1 & П1/П0 \\
\hline & нејунак & \multicolumn{2}{|c|}{$\mathrm{M} 0 / \Pi 2$} & M0 \\
\hline & неметал & M0 & $\mathrm{M} 0 / \Pi 2$ & $=\mathrm{PMC} 6$ \\
\hline & неотаи & П2 & M0 & l \\
\hline & неотпор & $\mathrm{M} 0 / \Pi 2$ & M0 & / \\
\hline & неплемић & П1/П3 & $\begin{array}{l}\Pi 1 / \Pi 3 / \\
\text { M0/M1 }\end{array}$ & / \\
\hline & непокој & M0 & $\mathrm{M} 0 / \Pi 2$ & l \\
\hline & непостојање & т. 1.3 .5 .4 & \multicolumn{2}{|c|}{ M0 } \\
\hline & непотреба & $\Pi 1$ & П0 & l \\
\hline & нерод & П0 & П0/П1 & I \\
\hline & несећане & $\Pi 0$ & $\Pi 1$ & I \\
\hline & несподоба & П0/M1 & $\begin{array}{c}\text { П2/M0/ } \\
\text { П0/M1 }\end{array}$ & l \\
\hline & неукус & П0/M1 & \multicolumn{2}{|c|}{ П0 } \\
\hline & нехришћанин & П2 & М0/П2 & M0 \\
\hline & нечовештво & $\mathrm{M} 0 / \Pi 2$ & т. 1.3 .5 .5 & l \\
\hline \multirow{2}{*}{ по- } & покћерка & $\Pi 2 / \Pi 3$ & $\Pi 3$ & l \\
\hline & помајка & \multicolumn{2}{|c|}{ П1 } & П0 \\
\hline \multirow{9}{*}{ под- } & подгрупа & П1 & l & П1/П3/М0/M1 \\
\hline & подзаповедник & \multicolumn{2}{|c|}{ M0 } & П1/П3/M0/M1 \\
\hline & пододбор & М0/П2 & M1 & l \\
\hline & подоснова & П1/П3 & $\begin{array}{l}\text { П1/П3/ } \\
\text { М0/M1 }\end{array}$ & / \\
\hline & подраса & П0 & П0/П2 & l \\
\hline & подшумар & $\Pi 1$ & П0/П1 & l \\
\hline & поткњижар & \multicolumn{2}{|c|}{ П1 } & П1/П3 \\
\hline & поткошуља & \multicolumn{2}{|c|}{ М0/П2 } & $\Pi 2$ \\
\hline & потпоручник & $\Pi 2$ & П0/П2 & $\Pi 2$ \\
\hline
\end{tabular}




\begin{tabular}{|c|c|c|c|c|}
\hline \multirow{16}{*}{ пра- } & пражитељ & M0 & $\begin{array}{l}\Pi 0 / \mathrm{M} 0 / \\
\mathrm{M} 1 / \mathrm{M} 2\end{array}$ & П0/П2 \\
\hline & празаметак & $\mathrm{M} 0 / \Pi 2$ & $\Pi 3$ & / \\
\hline & праизведба & $\Pi 2$ & \multicolumn{2}{|c|}{$\mathrm{M} 0 / \Pi 2$} \\
\hline & праизвор & $\Pi 2$ & \multicolumn{2}{|c|}{$\mathrm{M} 0 / \Pi 2$} \\
\hline & праинсект & $\Pi 2$ & \multicolumn{2}{|c|}{$\mathrm{M} 0 / \Pi 2$} \\
\hline & прајезик & П2 & $\mathrm{M} 0 / \Pi 2$ & M0 \\
\hline & пракичмењак & П2/П0 & $\begin{array}{l}\text { П0/M0/ } \\
\text { M1/M2 }\end{array}$ & П2/П0 \\
\hline & праколевка & $\Pi 2$ & $\mathrm{M} 0 / \Pi 2$ & / \\
\hline & пракрилаи & \multicolumn{2}{|c|}{$\Pi 2$} & $\mathrm{M} 0 / \Pi 2$ \\
\hline & праљускар & \multicolumn{2}{|c|}{$\Pi 0 / \Pi 2$} & $\Pi 0$ \\
\hline & nраотаu & $\Pi 2$ & $\mathrm{M} 0 / \Pi 2$ & $\Pi 2$ \\
\hline & прапостојбина & $\Pi 2$ & \multicolumn{2}{|c|}{ М0/П2 } \\
\hline & прапроизводна & П2 & M0 & / \\
\hline & прародитељь & $\Pi 2$ & $\mathrm{M} 0 / \Pi 2$ & M0 \\
\hline & прастановник & т. 1.3.5.3 & M0 & т. 1.3.5.3 \\
\hline & прасупстанција & $\Pi 2$ & $\mathrm{M} 0 / \Pi 2$ & / \\
\hline \multirow{10}{*}{ пред- } & преджсивот & $\Pi 2$ & $\mathrm{M} 0 / \Pi 2$ & $\Pi 2$ \\
\hline & предигра & \multicolumn{2}{|c|}{ П2 } & П0/П2 \\
\hline & предиспит & $\mathrm{M} 0 / \Pi 2$ & M0 & $\mathrm{M} 0 / \Pi 2$ \\
\hline & предисторија & $\mathrm{M} 0 / \Pi 2$ & M0 & $\mathrm{M} 0 / \Pi 2$ \\
\hline & преднаирт & \multicolumn{2}{|c|}{ M0 } & $\mathrm{M} 0 / \Pi 2$ \\
\hline & предуслов & \multicolumn{2}{|c|}{ M0 } & $\mathrm{M} 0 / \Pi 2$ \\
\hline & преткомора & $\Pi 3$ & П2 & $\Pi 3$ \\
\hline & претпакао & $\Pi 3$ & M0 & / \\
\hline & претпарламент & l & M0 & $\mathrm{M} 0 / \Pi 2$ \\
\hline & претфаза & / & M0 & М0/П2 \\
\hline
\end{tabular}




\begin{tabular}{|c|c|c|c|c|}
\hline \multirow{3}{*}{ при- } & примозак & $\Pi 1$ & П0/П1 & l \\
\hline & присподоба & П0 & $\begin{array}{l}\text { П0/M0/ } \\
\mathrm{M} 1 / \mathrm{M} 2\end{array}$ & l \\
\hline & пришав & П0 & П1 & l \\
\hline \multirow{4}{*}{ против- } & противдоказ & \multicolumn{2}{|c|}{ M0 } & т. 1.3.5.4 \\
\hline & противигра & / & M0 & $\mathrm{M} 0 / \mathrm{M} 1$ \\
\hline & противнапад & M0 & $\begin{array}{l}\text { П0/M0/ } \\
\mathrm{M} 1 / \mathrm{M} 2\end{array}$ & / \\
\hline & противтужба & \multicolumn{2}{|c|}{ M0 } & M0/M1 \\
\hline \multirow{2}{*}{ pa3- } & раскалуђер & \multicolumn{2}{|c|}{ П1/П3 } & M0 \\
\hline & расфратар & П0 & П1 & П0 \\
\hline \multirow{3}{*}{ ca- } & сакривач & П3 & М0/П3 & $\Pi 3$ \\
\hline & самилост & П1/П0 & \multicolumn{2}{|c|}{ П1 } \\
\hline & сауредник & $\Pi 2$ & $\mathrm{M} 0 / \Pi 2$ & / \\
\hline \multirow{2}{*}{ cy- } & субораи & \multicolumn{2}{|c|}{ M0 } & П1/П3 \\
\hline & сувозач & \multicolumn{2}{|c|}{ M0 } & $\mathrm{M} 0 / \Pi 2$ \\
\hline
\end{tabular}

\section{7. Закључак}

7.1. На основу испитаног корпуса, можемо рећи да на природу акценатских алтернација у префиксацији именица првенствено утичу следећи фактори:

1) акценат мотивне речи, и то:

a) његов квалитет;

б) удаљеност акцентованог слога од почетка речи;

2) силабичка структура префикса;

3) фонолошка природа морфемске границе између префикса и првог слога мотивне речи у добијеној мотивисаној речи;

4) угледање на друге творбене начине и типове.

7.2. Тон акцента мотивних речи утиче на следећи начин:

1) мотивне речи са силазним акцентима у највећем броју случајева граде мотивисане именице с краткосилазним на првом слогу (префикса); 
2) мотивне речи са узлазним акцентима у највећем броју случајева задржавају исти акценат у истој позицији и у мотивисаним именицама.

7.3. Што је узлазни акценат мотивне речи удаљенији од њеног првог слога, већа је могућност да ће у мотивисаној именици он ту и остати, али и да ће се на првом слогу (префикса) јавити други, краткосилазни, или секундарни акценат.

7.4. Двосложни префикси теже да образују именице са другим или секундарним акцентом на свом првом слогу и чувањем акцента мотивне речи у истој позицији где је и био пре префиксације.

7.5. Када се узлазни акценат мотивне чува у мотивисаној именици, у случају да је на граници префикса и првог слога мотивне речи тешко изговорљива консонантска група усред које долази јака силабичка граница, велика је вероватноћа да ће се на првом слогу (префикса) јавити и други или секундарни акценат.

7.6. На акценат малобројних примера у префиксацији може утицати акценат именица насталих префиксално-суфиксалном творбом које имају исти префикс и суфикс у морфемској структури, или пак имају исти фонемски завршетак.

7.7. Ретки примери се при образовању акцента мотивисане именице могу угледати на семантички сродне резултате у префиксалној творби, са истим префиксом, али другачијом природом акцента мотивне речи.

7.8. Квантитет слогова мотивне речи у највећем броју случајева остаје исти у префиксалној творби, док су изузеци углавном изазвани недоследностима или случајним омашкама у лексикографској обради, а у ретким случајевима и утицајем других творбених начина и модела.

7.9. У складу са анализом поменутих фактора, спремни смо предложити да је формирање акцента именице настале префиксалном творбом примарно резултат разрешавања макар три тежње, често и дублетним начинима, од којих су прве две и оштро супротстављене:

1) тежње мотивне речи да задржи своје тонске карактеристике, чијим се остварењем може добити једна од три варијанте:

a) узлазни акценат мотивне речи остаје на истом слогу;

б) силазни акценат најпре остаје, па се преноси метатонијски;

в) најређе, силазни акценат остаје на истом, сада унутрашњем слогу; 
2) тежње творбеног модела да потпуно неутралише акценат мотивне речи, чиме се обавезно остварује краткосилазни на првом слогу (префикса);

3) тежње прозодијске организације исказа да под одређеним факторима метричке структуре формира додатни/секундарни акценат.

\section{Извори}

PМС: Речник српскохрватскога књижевног језика. Друго фототипско издање. Нови Сад [- Загреб]: Матица српска [- Матица хрватска], 1990. [1967-1976]

OP: Мирослав Николић, Обратни речник српскога језика. Београд: Палчић, 2005.

PCJ 2011: Речник српскога језика, Друго, измењено и поправљено издање, Нови Сад: Матица српска, 2011. [2007]

\section{ЛИТЕРАТУРА}

Белић 1914: Александар Белић, Акценатске студије, Београд: Српска краљевска академија.

Белић 2000: Александар Белић, Универзитетска предавања из савременог српскохрватског језика / Библиографија радова Александра Белића, Изабрана дела Александра Белића, Четрнаести том, Београд: Завод за уџбенике и наставна средства.

Брборић 2012: Вељко Брборић, „Творба речи и правопис - писање сложених детерминативних формација са првом страном компонентом”, у: Творба речи и њени ресурси у словенским језицима - зборник радова са четрнаесте међународне научне конферениије Комисије за творбу речи при Међународном комитету слависта, Београд: Филолошки факултет, 485-496.

Даничић 1925: Ђура Даничић, Српски акценти, Београд - Земун: Графички завод „Макарије”.

Дешић 2018: Милорад Дешић, „Српски стандардни акценат и префиксација именица", Српски језик, XXIII, 179-189.

Драгићевић 2008: Рајна Драгићевић, „Актуелна питања науке о творби речи (на материјалу радова Комисије за творбу речи Међународног славистичког комитета)", Научни састанак слависта у Вукове дане, 36/3.

Драгићевић 2015: Рајна Драгићевић, „Префиксација у србистици и славистици", у: У простору лингвистичке славистике - зборник научних радова поводом 65 година живота академика Предрага Пипера, Београд : Филолошки факултет, 353-366. 
Ђуровић 2018: Сања Ђуровић, „Лексеме са префиксом не- у 'Госпођици' Иве Адрића", Српски језик: статус, систем, употреба - зборник у част проф. Милошу Ковачевићу, Крагујевац: Филолошко-уметнички факултет, 613-624.

Jип 2006: Moira Yip, "Tone", The Cambridge Handbook of Phonology, New York: Cambridge University Press, 229-252.

Јокановић-Михајлов 2006: Јелица Јокановић-Михајлов, Акценат и интонација говора на радију и телевизији, Београд: Друштво за српски језик и књижевност Србије.

Јокановић-Михајлов 2012: Јелица Јокановић-Михајлов, Прозодија и говорна култура, Београд: Друштво за српски језик и књижевност Србије.

Клајн 2002: Иван Клајн, Творба речи у савременом српском језику. Део 1, Слагање и префиксација, Београд: Завод за уџбенике и наставна средства - Институт за српски језик САНУ.

Марјановић 2004: Слободан Марјановић, „О творби именица префиксом без- (на корпусу неких књижевних дела Д. Ћосића)", Српски језик, IX/1-2, 585-590.

Маројевић 2011: Радмило Маројевић, „Ријечи с побочним акцентима : прозодијско-интонациона интерпретација текста Луче микрокозма”, Зборник Матице српске за филологију и лингвистику, LIV/1, 101-114.

Маројевић 2012: Радмило Маројевић, „Ријечи с двоструким (главним и побочним) акцентима - прозодијско-интонациона интерпретација текста Луче микрокозма”, Јужнословенски филолог, LXVIII, 49-69.

Николић 1962: Берислав М. Николић, „Акценатске алтернације у савременом српскохрватском књижевном језику", Јужнословенски филолог, XXV, 185-196.

Пецо-Пешикан 1967: Асим Пецо и Митар Пешикан, Информатор о савременом къижевном језику са речником, Београд: Младо поколење.

Радић 2005: Јованка Радић, „Префиксална творба речи - деривација или композиција (наставни и ваннаставни аспект)", Наш језик, 36/1-4, 54-67.

Радовић Тешић 2002: Милица Радовић Тешић, Именице с префиксима у српском језику, Београд: Институт за српски језик САНУ.

Радовић Тешић 2004: Милица Радовић Тешић, „Богаћење лексике префиксацијом”, Српски језик, IX/1-2, 219-226.

Ристић 2009: Стана Ристић, „Неке најновије појаве у развоју лексике српског језика (на примеру твореница са префиксима не- и анти-)", Научни састанак слависта у Вукове дане, 38/1, 27-41.

Стевановић 1991: Михаило Стевановић, Кюига о акиенту књижевног јези$\kappa a$, Београд: Завод за уџбенике и наставна средства.

Ћорић 2008а: Божо Ћорић, „Стране препозитивне компоненте у структури сложене номинативне јединице", Научни састанак слависта у Вукове дане, 36/3, 33-59.

Ћорић 2008б: Божо Ћорић, Творба именииа у српском језику, Београд: Друштво за српски језик и књижевност Србије. 
Ћорић 2015: Божо Ћорић, „Кратак преглед творбе речи у српском језику”, Путевима српског језика, књижевности и културе - скуп слависта, предавања 1, Београд: Филолошки факултет - Међународни славистички центар, 117-138.

Фокс 2000: Anthony Fox, Prosodic Features and Prosodic Structure. New York: Oxford University Press.

Nikola V. Radosavljević

\section{WORD ACCENT IN NOUN PREFIXATION}

\section{Summary}

The paper examines prosodic alternations in noun-to-noun prefixation in the standard Serbian language. The author analyses the prosodic relations among bases and derived words for every prefix and derivational nest (such as tonal, quantitive and stress alternations). Additionally, this paper postulates a typology of these alternations based on the prosodic and word formation criteria. In some cases the author proposes different possibilities that are not represented in the normative literature of standard Serbian language. The main goal of the article is to contribute to research and understanding of word accent in word formation.

Keywords: modern Serbian language, prosody, word accent, prosodic alternations, prefixation, nouns. 